\title{
Original
}

\section{Glucose promotes its own metabolism by acting on the cell-surface glucose-sensing receptor T1R3}

\author{
Yuko Nakagawa, Yoshiaki Ohtsu, Masahiro Nagasawa, Hiroshi Shibata and Itaru Kojima \\ Institute for Molecular \& Cellular Regulation, Gunma University, Maebashi 371-8512, Japan
}

\begin{abstract}
A homodimer of taste type 1 receptor 3 (T1R3) functions as a sweet taste-sensing receptor in pancreatic $\beta$-cells. This receptor is activated by various sweet molecules including sugars such as glucose. To determine the role of this receptor in glucose-induced insulin secretion, we addressed whether or not this receptor modulates glucose metabolism in MIN6 cells. We measured changes in intracellular ATP $\left([\mathrm{ATP}]_{\mathrm{i}}\right)$ in MIN6 cells expressing luciferase. Sucralose, an agonist of T1R3, induced immediate and sustained elevation of $[\mathrm{ATP}]_{\mathrm{i}}$ in the presence of $5.5 \mathrm{mM}$ glucose. The effect of sucralose was dose-dependent and, at $5 \mathrm{mM}$, was greater than that induced by $25 \mathrm{mM}$ glucose. In contrast, carbachol, GLP-1 or high concentration of potassium did not reproduce the sucralose action. Sucralose facilitated the increase in $[\text { ATP }]_{\mathrm{i}}$ induced by a mitochondrial fuel methylsuccinate, and potentiated glucose-induced elevation of $[\mathrm{ATP}]_{\mathrm{i}}$. Administration of a nonmetabolizable glucose analogue, 3-O-methylglucose, which acts as an agonist of T1R3, induced a small and transient increase in $[\mathrm{ATP}]_{\mathrm{i}}$. 3-O-Methylglucose augmented elevation of $[\mathrm{ATP}]_{\mathrm{i}}$ induced by methylsuccinate, and also enhanced glucose-induced increase in $[\mathrm{ATP}]_{\mathrm{i}}$. Knock down of T1R3 by using shRNA attenuated $[\mathrm{ATP}]_{\mathrm{i}}$-response to high concentration of glucose and also reduced the glucose-induced insulin secretion. These results indicate that activation of the homodimer of T1R3 facilitates the metabolic pathway in mitochondria and augments ATP production. The results obtained by using 3-O-methylglucose suggest that glucose, by acting on the homodimer of T1R3, promotes its own metabolism.
\end{abstract}

Key words: Insulin, Pancreatic $\beta$-cell, Glucose, Sweet taste receptor, ATP

INSULIN is secreted from pancreatic $\beta$-cells and regulates metabolism of glucose and other nutrients in the body. On the other hand, the $\beta$-cell functions as a nutrient sensor and detects changes in nutrients in the blood stream. Among various nutrients, glucose is the most important regulator of insulin secretion. According to the current understanding, glucose enters the $\beta$-cell via glucose transporters and is then metabolized through the glycolytic pathway and in mitochondria. The resultant increase in adenosine triphosphate (ATP) and decrease in adenosine diphosphate (ADP) close the ATP-sensitive potassium $\left(\mathrm{K}_{\mathrm{ATP}}\right)$ channel in the plasma membrane, which leads to depolarization of the plasma membrane followed by an opening of the voltage-gated calcium channel. Massive calcium that entered through this channel triggers exocytosis of

Submitted Oct. 15, 2013; Accepted Oct. 17, 2013 as EJ13-0431 Released online in J-STAGE as advance publication Nov. 7, 2013

Correspondence to: Itaru Kojima, M.D., Institute for Molecular \& Cellular Regulation, Gunma University, Maebashi 371-8512, Japan. E-mail: ikojima@k4.dion.ne.jp insulin $[1,2]$. In addition, glucose also amplifies insulin secretory response by a mechanism independent of the $\mathrm{K}_{\text {ATP }}$ channel activation $[2,3]$.

We reported previously that the sweet taste receptor is expressed in pancreatic $\beta$-cells [4]. Activation of this receptor by artificial sweeteners results in stimulation of insulin secretion [4]. In this regard, the sweet taste receptor in $\beta$-cells is functional. The sweet taste receptor is a heterodimer of taste type 1 receptor 2 (T1R2) and T1R3, and is a multifunctional receptor that binds a variety of sweet molecules including sugars, amino acids, polypeptides, proteins, glycosides and various artificial sweeteners with diverse chemical structures $[5,6]$. With regard to the physiology of $\beta$-cells, the most interesting agonist is glucose among numerous agonists for the sweet taste receptor. Although the affinity of glucose to the sweet taste receptor is not high in the taste buds, the fact that functional sweet taste receptor is expressed in $\beta$-cells implies that this receptor is activated by plasma glucose at least to some extent, and may be involved in glucose-induced insu- 
lin secretion. A crucial question is to what extent the sweet taste receptor is involved in the glucose-induced insulin secretion and how it is regulated in $\beta$-cells [7, 8]. This question should be addressed experimentally. We showed recently that the expression of T1R2 is quite low compared to that of T1R3 in pancreatic $\beta$-cells [9]. Furthermore, knock down of T1R3 attenuates the effect of sweet molecules whereas knock down of T1R2 is without effect [9]. These observations suggest that a homodimer of T1R3 functions as a sweet taste-sensing receptor in $\beta$-cells.

In an attempt to examine the role of the homodimer of T1R3 in pancreatic $\beta$-cells, we investigated whether or not this receptor modulates metabolism of glucose. To this end, we monitored changes in intracellular ATP $\left([\mathrm{ATP}]_{\mathrm{i}}\right)$ in glucose-responsive MIN6 cells transfected with the luciferase gene. The results show a novel function of the homodimer of T1R3 in $\beta$-cells. Namely, activators of the homodimer of T1R3 increase ATP by promoting metabolism presumably in mitochondria. In addition, non-metabolizable glucose analogue 3-O-methylglucose acts on the receptor and increases ATP. Indeed, these results provide a new insight into the mechanism of action of glucose in $\beta$-cells. Glucose first acts on the cell surface glucose-sensing receptor T1R3 and generates signals which activate the metabolic pathway inside $\beta$-cells. Then glucose enters $\beta$-cells, and is metabolized through the primed metabolic pathway, which leads to the production of ATP, and eventually induction of insulin secretion.

\section{Materials and Methods}

\section{Cell culture}

MIN6 cells (passages 16-21) [10] were grown in Dulbecco's modified Eagle's medium containing high glucose (Life Technologies, Carlsbad, CA, USA), 50 $\mu \mathrm{M} \quad \beta$-mercaptorthanol, $70 \mu \mathrm{g} / \mathrm{ml}$ benzylpenicillin potassium, $100 \mu \mathrm{g} / \mathrm{ml}$ streptomycin sulfate and $15 \%$ fetal bovine serum (Sigma-Aldrich, St. Louis, MO, USA) and maintained in humidified incubator $95 \%$ air and $5 \% \mathrm{CO}_{2}$ at $37^{\circ} \mathrm{C}$.

\section{Transfection of plasmid DNA}

MIN6 cells grown on a $100 \mathrm{~mm}$ culture dish were dispersed with PBS containing 0.05\% trypsin-EDTA (Life Technologies). After washing with growth medium, cells were resuspended in Electroporation Buffer (Bio-Rad, Hercules, CA, USA). A $0.55 \mathrm{ml}$ of cell aliquot was mixed with $0.2 \mathrm{ml}$ of the pGL4.51 (Promega KK, Madison, WI, USA) or GW1CMVPerceval (Addgene, Cambridge, MA, USA) $(30 \mu \mathrm{g})$ in a $0.4 \mathrm{~cm}$-gap cuvette before single pulse of electroporation was administered by using Gene Pulser Xcell (Bio-Rad) set at voltage $200 \mathrm{~V}$ and time constant 28 msec. The cells expressing pGL4.1 were resuspended in growth medium, seeded on a CulturePlate-96, white, TC (PerkinElmer, Waltham, MA, USA). The cells expressing GW1CMV-Perceval were resuspended in growth medium, seeded on a $35 \mathrm{~mm}$ glass bottom culture dish (MatTek, Ashland, MA, USA).

\section{Measurement of intracellular ATP}

MIN6 cells were seeded into CulturePlate-96, white, TC and incubated for 2-3 days before measurement of ATP. Cells were incubated for $20 \mathrm{~min}$ in Hank's Solution "Nissui" (Nissui Pharmaceutical, Tokyo, Japan) containing $20 \mathrm{mM}$ HEPES-NaOH (pH 7.4) and $50 \mu \mathrm{M}$ D-luciferin potassium salt (Wako Pure Chemical Industries, Osaka, Japan) in a $37^{\circ} \mathrm{C}$ incubator. In some experiments, we used Krebs-Ringer bicarbonate buffer and the results were essentially the same. To measure the basal ATP concentration $\left(\mathrm{L}_{0}\right)$, we counted the emitted photons with an EnSpire (Perkin Elmer) for 20 $\mathrm{min}$. The cells were then incubated in the presence or absence of stimulatory substances. Subsequently, we counted the emitted photons for $1 \mathrm{~h}$. These values (L) were normalized to each basal value $\left(\mathrm{L}_{0}\right)$ so that the relative luminescence change was referred to as $\mathrm{L} / \mathrm{L}_{0}$. For calculations of luminescence change, we subtracted the $\mathrm{L} / \mathrm{L}_{0}$ of the absence of stimulatory substances from that of the presence of stimulatory substances.

\section{Measurement of cytosolic ATP/ADP by Perceval}

Before the measurement, growth medium was removed and washed with Hank's solution twice. After washing, cells were resuspended in the same buffer, and incubated for $20 \mathrm{~min}$. Cells were visualized with a 40 Uapo/340 objective lens (Olympus, Tokyo, Japan). Perceval [11] was excited with the wavelength of $488 \mathrm{~nm}$. Images (100 ms exposure) were captured with a C7780-22 ORCA3CCD camera (Hamamatsu Photonics) at $10 \mathrm{sec}$ intervals. These values (F) were normalized to the initial value $\left(\mathrm{F}_{0}\right)$ so that the relative fluorescence change was referred to as $\mathrm{F} / \mathrm{F}_{0}$.

\section{RNA interference}

The expression level of T1R3 was reduced by using 
a GIPZ lentivial shRNA (clone ID, V3LMM 441299, Thermo Scientific, Waltham, MA, USA). Control cells were transfected with a pGLPZ non-silencing shRNAmir lentiviral control vector (Thermo Scientific).

\section{Isolation of total RNA and quantitative RT-PCR}

Total RNA isolated from MIN6 cells by using the TRIZOL Reagent (Invitrogen, Carlsbad, CA) was used for cDNA synthesis using a Transcriptor First Strand cDNA Synthesis Kit (Roche Applied Science, Mannheim, Germany). The cDNA was used for quantitative RT-PCR template using Faststart Universal SYBR Green Master (Roche Applied Science) and the following primer sets. For T1R3 mRNA, the forward primer was 5'-AAGGCCTGCAGTGCACAAGA-3' and the reverse primer was 5'-GGCCTTAGGTGGGCATAATAGGA-3'. For control $\beta$-actin mRNA, the forward primer was 5'-AGGATGCAGAAGGAGATTACTG-3' and the reverse primer was 5'-GCTGATCCACATCTGCTGGAA-3'. The reaction was performed on an Applied Biosystems ViiA 7 Real-Time PCR system (Applied Biosystem, Carlsland, CA, USA).

\section{Measurement of insulin secretion}

MIN6 cells were seeded into 24-well plates and incubated for $48 \mathrm{hrs}$ before measurement of insulin secretion. Cells were preincubated for $1 \mathrm{hr}$ in Krebs-Ringer bicarbonate buffer containing $0.1 \%$ bovine serum albu$\min$ in a $37^{\circ} \mathrm{C}$ humidified incubator. The cells were then incubated for $60 \mathrm{~min}$ in the same buffer containing various stimulators. The supernatant was collected and centrifuged at $300 \mathrm{x} \mathrm{g}$ for $10 \mathrm{~min}$ to remove cell debris. The insulin concentration was measured by radioimmunoassay (Eiken Chemical, Tokyo, Japan) according to the manufactures protocol. The insulin secretion data were normalized by insulin content. Statistical analysis was done by using Student t-test. For statistical analysis of insulin secretion, one-way ANOVA was used.

\section{Results}

We monitored changes in $[\mathrm{ATP}]_{\mathrm{i}}$ in MIN6 cells transfected with the luciferase gene. As shown in Fig. 1A, elevation of ambient glucose concentration from 5.5 to $8.3 \mathrm{mM}$ resulted in an increase in $[\mathrm{ATP}]_{\mathrm{i}}$. The effect of high concentration of glucose was in fact biphasic: an initial small peak was observed within $1 \mathrm{~min}$, which was followed by a second sustained elevation of $[\mathrm{ATP}]_{\mathrm{i}}$.
The effect of glucose was dose-dependent (Fig. 1B). To determine the role of mitochondria, we added 2,4dinitrophenol to block the mitochondrial function. As shown in Fig. 1C, addition of $2 \mathrm{mM}$ 2,4-dinitrophenol in the presence of $5.5 \mathrm{mM}$ glucose induced a rapid and profound decrease in $[\mathrm{ATP}]_{\mathrm{i}}$ indicating a role of mitochondria in maintaining the ATP levels. Fig. 1D shows the effect of $4 \mathrm{mM}$ 2-cyclohexen-1-one, an inhibitor of glucokinase [11], on ATP levels. As depicted, addition of 2-cyclohexen-1-one reduced [ATP $]_{\mathrm{i}}$ immediately. To confirm accuracy of the measurement of $[\mathrm{ATP}]_{\mathrm{I}}$, we monitored changes in intracellular ATP/ADP using Perceval [11]. As shown in Fig. 1E, high concentration of glucose induced an elevation of ATP/ADP. This result was consistent with the changes in $[\mathrm{ATP}]_{\mathrm{i}}$ shown in Fig. 1A.

Next, we examined the effect of sucralose, an agonist for T1R3, on $[\mathrm{ATP}]_{\mathrm{i}}$. Sucralose is an artificial sweetener and is not metabolized in $\beta$-cells. When 3 $\mathrm{mM}$ sucralose was added in the presence of $5.5 \mathrm{mM}$ glucose, it induced an immediate elevation of $[\mathrm{ATP}]_{\mathrm{i}}$ which was followed by a sustained plateau (Fig. 2A). The effect of sucralose was dose-dependent (Fig. 2B). The effect of sucralose was observed at $0.5 \mathrm{mM}$, and at $10 \mathrm{mM}$, sucralose induced a response of $[\mathrm{ATP}]_{\mathrm{i}}$ which was much greater than that induced by $25 \mathrm{mM}$ glucose. Next, MIN6 cells were incubated in glucose-free medium for $60 \mathrm{~min}$ and $10 \mathrm{mM}$ sucralose was added in the absence of ambient glucose. Basal level of $[\mathrm{ATP}]_{\mathrm{i}}$ was lower in cells incubated for $60 \mathrm{~min}$ in glucose-free medium. Although the magnitude of the response was smaller, the effect of sucralose was observed in these cells (Fig. 2C). In fact, the magnitude of the initial peak was approximately $70 \%$ of that in the presence of $5.5 \mathrm{mM}$ glucose, and the plateau level was approximately $50 \%$ of that obtained in the presence of $5.5 \mathrm{mM}$ glucose. We then studied the interaction of glucose and sucralose. As shown in Fig. 2D, $8.3 \mathrm{mM}$ glucose induced a biphasic elevation of $[\mathrm{ATP}]_{\mathrm{i}}$. Sucralose (5 $\mathrm{mM}$ ) induced a rapid and sustained elevation of $[\mathrm{ATP}]_{\mathrm{i}}$. When glucose and sucralose were added together, the effects of these two agents were more than additive. Fig. 2E shows the area under the curve (AUC) of the effects of sucralose and/or glucose. As depicted, the effect of $8.3 \mathrm{mM}$ glucose and sucralose was greater than the sum of the effects of two stimulants. We then examined the effects of other insulin secretagogues on $[\mathrm{ATP}]_{\mathrm{i}}$. When $10 \mu \mathrm{M}$ carbachol, which induces breakdown of phosphoinositides and elevates cytoplasmic 

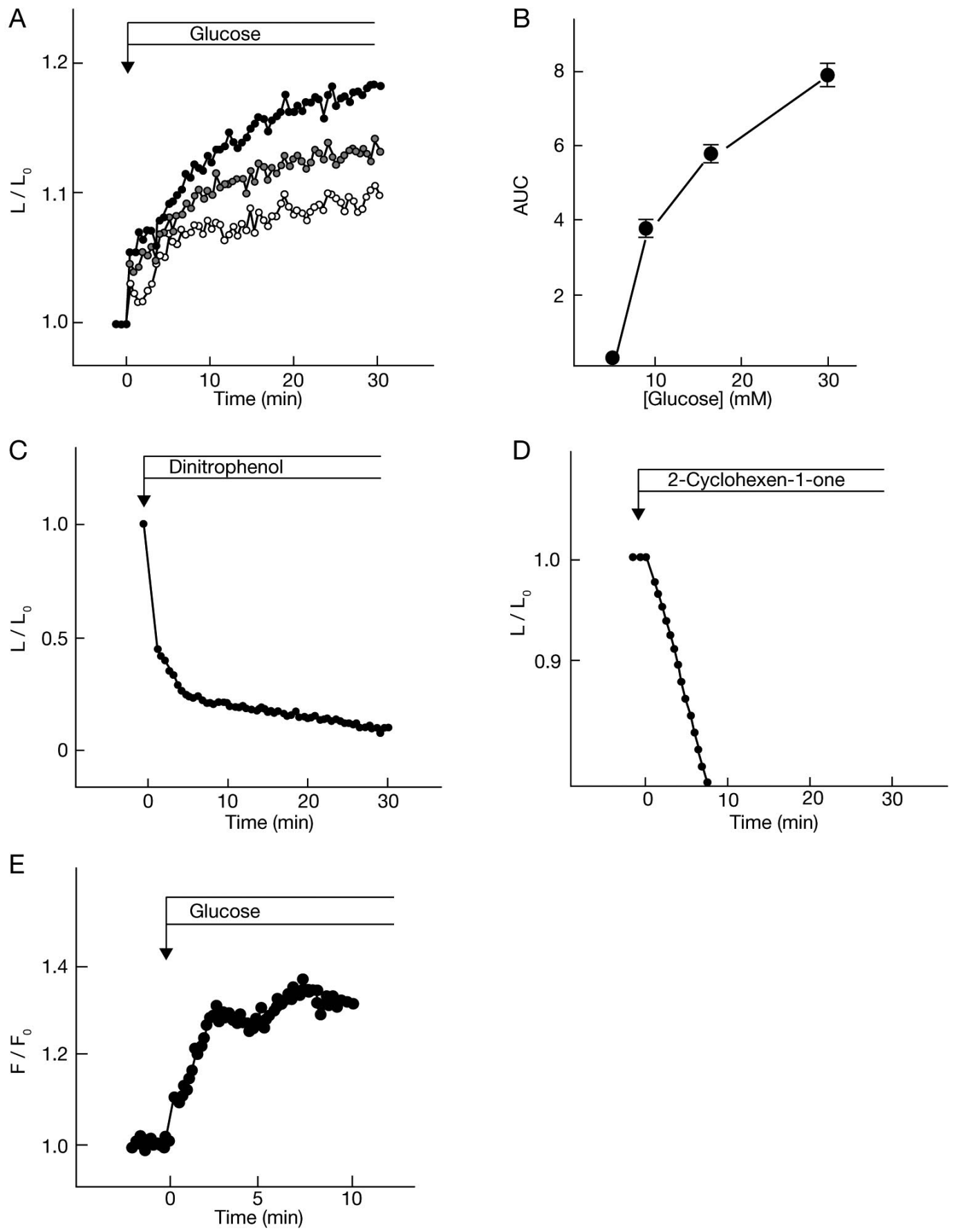

Fig. 1 Effect of glucose on $[\mathrm{ATP}]_{\mathrm{i}}$ in MIN6 cells

A: Effect of Glucose on $[\mathrm{ATP}]_{\mathrm{i}}$. Ambient glucose concentration was raised from $5.5 \mathrm{mM}$ to $8.3 \mathrm{mM}(\mathrm{O}), 16.7 \mathrm{mM}(\mathrm{O})$ and $25 \mathrm{mM}(\bullet)$ and changes in $[\mathrm{ATP}]_{\mathrm{i}}$ were monitored. Values are the mean $\pm \mathrm{SE}$ of three determinations and representative of five experiments. Note that error bars are too small to be visible. B: Dose-response Relationship for the Effect of Glucose on $[\mathrm{ATP}]_{\mathrm{i}}$. Changes in $[\mathrm{ATP}]_{\mathrm{i}}$ were measured as mentioned above and the area under the curve (AUC) was calculated. Values are the mean $\pm \mathrm{SE}$ for five experiments. C: Effect of 2, 4-Dinitophenol on $[\mathrm{ATP}]_{\mathrm{i}}$ in MIN6 Cells. MIN6 cells were incubated in Hank's solution containing $5.5 \mathrm{mM}$ glucose and $2 \mathrm{mM} \mathrm{2,4-dinitrophenol} \mathrm{was} \mathrm{added} \mathrm{as} \mathrm{indicated} \mathrm{by} \mathrm{the} \mathrm{arrow.} \mathrm{Values} \mathrm{are}$ the mean $\pm \mathrm{SE}$ of three determinations and the representative of three experiments. D: Effect of an Inhibitor of Glucokinase on $[\mathrm{ATP}]_{\mathrm{i}}$. MIN6 cells were incubated in Hank's solution containing $5.5 \mathrm{mM}$ glucose and $4 \mathrm{mM}$ 2-cyclohexen-1-one was added as indicated by the arrow. Values are the mean $\pm \mathrm{SE}$ of three determinations and the representative of three experiments. E: Effect of Glucose on the Ratio of Intracellular ATP/ADP Measured by Perceval. A MIN6 cell expressing Perceval was stimulated by $25 \mathrm{mM}$ glucose as indicated by the arrow. The result is a representative trace obtained in three experiments. 
free calcium concentration $\left(\left[\mathrm{Ca}^{2+}\right]_{\mathrm{c}}\right)$ [4], was added in the presence of $5.5 \mathrm{mM}$ glucose, the levels of $[\mathrm{ATP}]_{\mathrm{i}}$ were not changed significantly (Fig. 2F). Likewise, 100 nM GLP-1, which increases cAMP [4], did not affect $[\mathrm{ATP}]_{\mathrm{i}}$ significantly. When $40 \mathrm{mM} \mathrm{KCl}$, which increases $\left[\mathrm{Ca}^{2+}\right]_{\mathrm{c}}$ by stimulating calcium entry via voltage-gated $\mathrm{Ca}^{2+}$ channel, was added in the presence of $5.5 \mathrm{mM}$ glucose, there was a small increase in $[\mathrm{ATP}]_{\mathrm{i}}$, which was followed by a profound decrease in $[\mathrm{ATP}]_{\mathrm{c}}$ (Fig. 2F). We then investigated whether or not sucralose promoted metabolism in mitochondria. To this end, we added a mitochondrial fuel methyl-succinate, a cell-permeable analogue of succinate. As shown in Fig. 3A, $10 \mathrm{mM}$ methyl-succinate induced a rapid and sustained elevation of $[\mathrm{ATP}]_{\mathrm{i}}$. The effect of methylsuccinate was dose-dependent (Fig. 3B) and $50 \mathrm{mM}$ methylsuccinate induced a marked elevation of $[\mathrm{ATP}]_{\mathrm{I}}$ (data not shown). When sucralose was added together with methylsuccinate, these two compounds induced a synergistic effect and there was a marked sustained elevation of $[A T P]_{i}$ (Fig. 3C). Fig. 3D shows AUC of the effects of methylsuccinate and/or sucralose. As depicted, the effects of methylsuccinate and sucralose were synergistic.

The above results indicate that activation of the homodimer of $\mathrm{T} 1 \mathrm{R} 3$, increased $[\mathrm{ATP}]_{\mathrm{i}}$ presumably by promoting metabolism in mitochondria. A critical question is whether or not high concentration of glucose is able to activate this receptor and promote its own metabolism. To test this possibility, we examined the effects of non-metabolizable analogues of glucose, 3-O-methylglucose and 2-deoxyglucose. Fig. 4A shows the comparison of the effects of glucose, 3-Omethylglucose and 2-deoxyglucose. As mentioned above, elevation of glucose from 5.5 to $25 \mathrm{mM}$ caused biphasic increase in $[\mathrm{ATP}]_{\mathrm{i}}$. In contrast, a non-metabolizable glucose analogue 3-O-methylglucose $(25$ $\mathrm{mM}$ ) induced a rapid and transient elevation of $[\mathrm{ATP}]_{\mathrm{i}}$ in the presence of $5.5 \mathrm{mM}$ glucose, which resembled the first peak of the glucose-induced $[\mathrm{ATP}]_{\mathrm{i}}$ response. $[\mathrm{ATP}]_{\mathrm{i}}$ level returned to the basal value by $10 \mathrm{~min}$ and remained at the basal level. 2-Deoxyglucose is a nonmetabolizable glucose analogue, which also inhibits the glucokinase activity. When $25 \mathrm{mM}$ 2-deoxyglucose was added in the presence of $5.5 \mathrm{mM}$ glucose, there was a rapid and transient elevation of $[\mathrm{ATP}]_{\mathrm{i}}$. However, this small peak was followed by a gradual decrease in $[\mathrm{ATP}]_{\mathrm{i}}$ and the sustained level was below the basal level. When mannoheptulose, an inhibitor of glucokinase [12], was added, a small increase in $[\mathrm{ATP}]_{\mathrm{I}}$ was observed, which was followed by a gradual decrease in $[\mathrm{ATP}]_{\mathrm{i}}$ (Fig. 4B). The effect of 3-O-methylglucose was dose-dependent. As shown in Fig. 4C, when $11 \mathrm{mM} 3-O$-methylglucose was added in the presence of $5.5 \mathrm{mM}$ glucose, this glucose analogue induced a small and transient elevation of $[\mathrm{ATP}]_{\mathrm{i}}$. At $25 \mathrm{mM}$, 3-O-methylglucose evoked a larger increase in $[\mathrm{ATP}]_{\mathrm{i}}$. Furthermore, $50 \mathrm{mM}$ 3-O-methylglucose induced much greater response of $[\mathrm{ATP}]_{\mathrm{i}}$. Fig. $4 \mathrm{D}$ shows the dose-response curve for the effect of 3-O-methylglucose on $[\mathrm{ATP}]_{\mathrm{i}}$.

We then studied the effect of knock down of T1R3. T1R3 was knocked down by adding siRNA. As shown in Fig. 5A, the expression of T1R3 was reduced approximately $70 \%$ by the addition of siRNA. In these cells, the effect of sucralose on $[\mathrm{ATP}]_{\mathrm{i}}$ was markedly reduced (Fig. 5B). When $25 \mathrm{mM}$ glucose was added to these cells, the first peak of $[\mathrm{ATP}]_{\mathrm{i}}$ was attenuated and the second phase was also inhibited partially (Fig. 5C). As shown in Fig. 5D, knock down of T1R3 significantly reduced both the first and second phases of the glucoseinduced $[\mathrm{ATP}]_{\mathrm{i}}$ response.

As shown in Fig. 4C, non-metabolizable glucose analogue 3-O-methylglucose induced a rapid and transient elevation of $[\mathrm{ATP}]_{\mathrm{i}}$. To determine if this transient effect of non-metabolizable glucose had an impact on metabolism in mitochondria, we examined whether or not 3-O-methylglucose modified the effect of methylsuccinate. As shown in Fig. 6A, addition of 3-O-methylglucose enhanced elevation of $[\mathrm{ATP}]_{\mathrm{I}}$ induced by low concentration of methylsuccinate. Fig. 6B shows quantitative analysis of the effect of 3-O-methylglucose on the methylsuccinate-induced elevation of $[\mathrm{ATP}]_{\mathrm{i}}$. As can be seen, the effects of two compounds are more than additive indicating that 3-O-methylglucose augmented metabolism of succinate.

We also determined if 3-O-methylglucose augmented $[\mathrm{ATP}]_{\mathrm{i}}$ response to $8.3 \mathrm{mM}$ glucose. As shown in Fig. 6C, $8.3 \mathrm{mM}$ glucose induced a biphasic increase in $[\mathrm{ATP}]_{\mathrm{i}}$ and $25 \mathrm{mM} \mathrm{3-O-methylglucose}$ induced a transient elevation of $[\mathrm{ATP}]_{\mathrm{i}}$. This concentration of 3-O-methylglucose augmented both the first and second phases of the $[\mathrm{ATP}]_{\mathrm{i}}$ response to $8.3 \mathrm{mM}$ glucose (Fig. 6D).

Finally, we measured insulin secretion in T1R3 knocked down cells. As shown in Fig. 7, insulin secretion-induced by $25 \mathrm{mM}$ glucose was significantly attenuated in MIN6 cells with reduced T1R3 expression. 

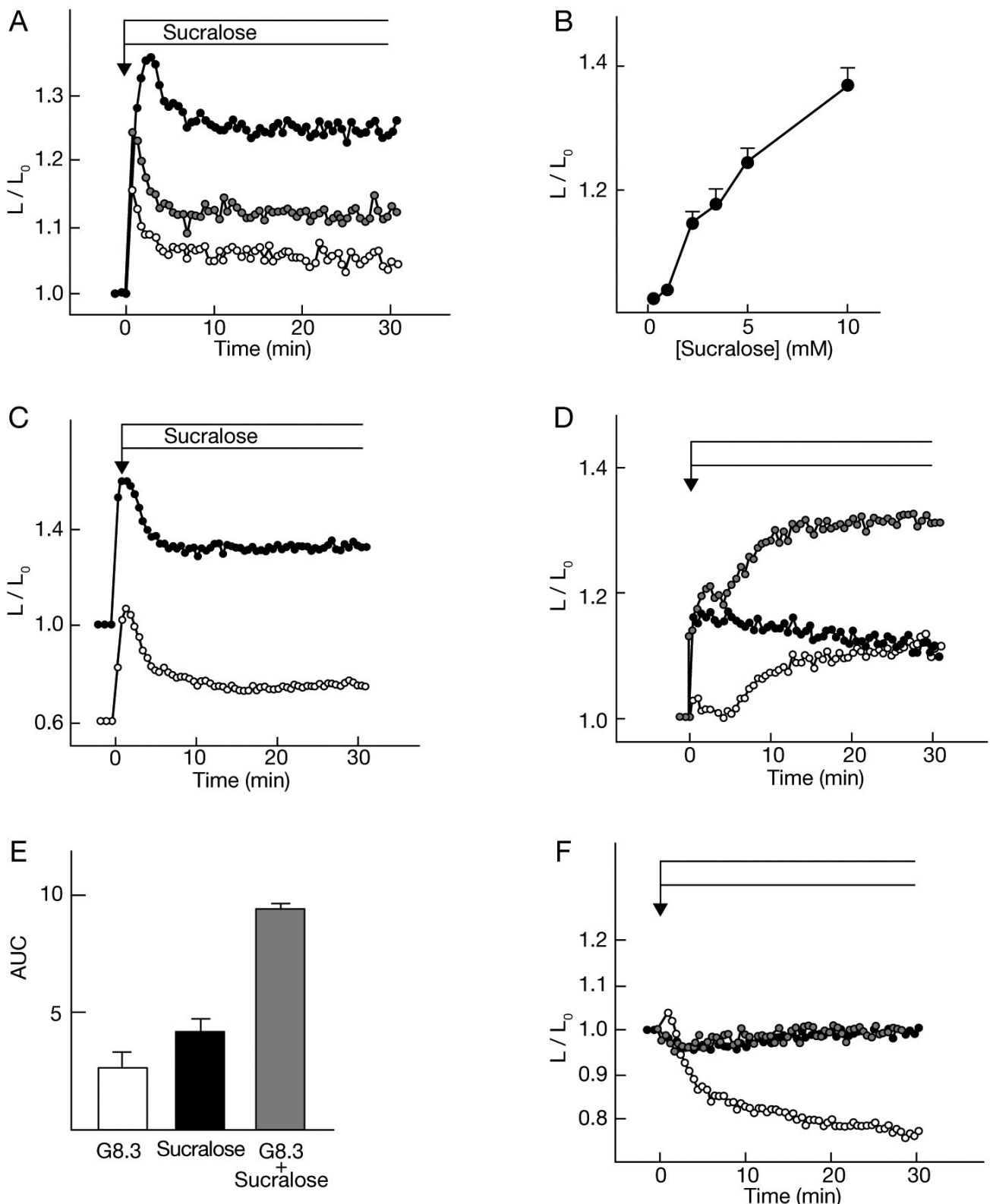

Fig. 2 Effect of sucralose on $[\mathrm{ATP}]_{\mathrm{i}}$ in MIN6 cells

A: Effect of Sucralose on [ATP] . MIN6 cells were incubated in Hank's solution containing $5.5 \mathrm{mM}$ glucose and $3 \mathrm{mM}$ $(\bigcirc), 5 \mathrm{mM}(\bigcirc)$ and $10 \mathrm{mM}(\bullet)$ sucralose was administered as indicated by the arrow. Values are the mean $\pm \mathrm{SE}$ of three determinations and the representative of five experiments. B: Dose-response Relationship for the Sucralose Effect on $[\text { ATP }]_{i}$. MIN6 cells were incubated with various concentrations of sucralose in the presence of $5.5 \mathrm{mM}$ glucose. The peak height was plotted as a function of concentration of sucralose. Values are the mean $\pm \mathrm{SE}$ of three to five determinations. C: Effect of Sucralose on $[\mathrm{ATP}]_{i}$ in the Absence of Glucose. MIN6 cells were incubated in Hank's solution containing $0(\mathrm{O})$ or $5.5 \mathrm{mM}$ (•) glucose for $60 \mathrm{~min}$ and then $10 \mathrm{mM}$ sucralose was administered as indicated by the arrow. Values are the mean $\pm \mathrm{SE}$ of three determinations and the representative of three experiments. D: Effect of Sucralose on Glucose-induced Elevation of $[\mathrm{ATP}]_{\mathrm{i}}$. MIN6 cells were incubated in Hank's solution containing $5.5 \mathrm{mM}$ glucose and then ambient glucose concentration was raised to $8.3 \mathrm{mM}$ in the presence $(O)$ and absence $(O)$ of $5 \mathrm{mM}$ sucralose. In some experiments, $5 \mathrm{mM}$ sucralose was added in the presence of $5.5 \mathrm{mM}$ glucose $(\bullet)$. Values are the mean $\pm \mathrm{SE}$ of three determinations and the representative of three experiments. E: Quantitative Analysis of the Effects of Glucose and Sucralose. Changes in [ATP] $]_{i}$ were measured as mentioned in D and AUC was calculated. Values are the mean \pm SE for three experiments. F: Effect of Carbachol, GLP-1 and High Concentration of Potassium on [ATP $]_{\text {i. }}$ MIN6 cells were incubated in Hank's solution containing $5.5 \mathrm{mM}$ glucose and

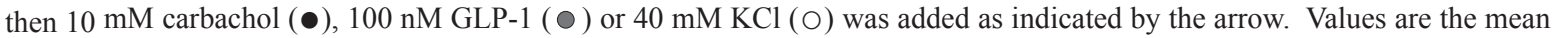
$\pm \mathrm{SE}$ of three determinations and the representative of three experiments. 

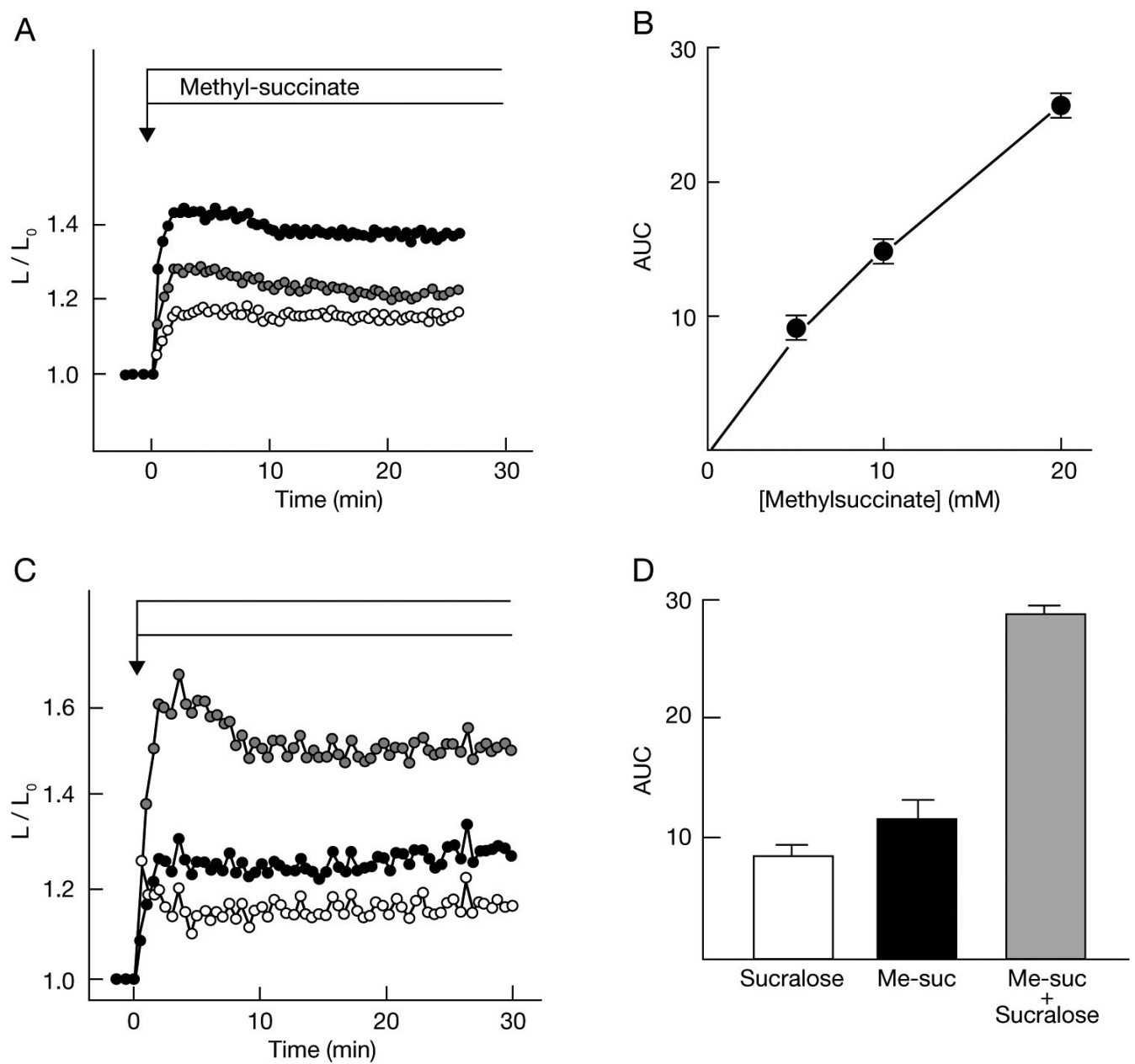

Fig. 3 Effect of sucralose on succinate-induced elevation of $[\mathrm{ATP}]_{\mathrm{i}}$

A: Effect of Methylsuccinate on $[\mathrm{ATP}]_{\mathrm{i}}$. MIN6 cells were incubated in Hank's solution containing $5.5 \mathrm{mM}$ glucose. Then, 5 $\mathrm{mM}(\mathrm{O}), 10 \mathrm{mM}(\odot)$ or $20 \mathrm{mM}(\bullet)$ methylsuccinate was added as indicated by the arrow. Values are the mean $\pm \mathrm{SE}$ of three determinations and the representative of three experiments. B: Dose-response Relationship for the Effect of Methylsuccinate on $[\mathrm{ATP}]_{\mathrm{i}}$. Changes in $[\mathrm{ATP}]_{\mathrm{i}}$ were measured as mentioned in A and AUC was calculated. Values are the mean $\pm \mathrm{SE}$ for three experiments. C: Effect of Sucralose on Methylsuccinate-induced Elevation of [ATP]i. MIN6 cells were incubated in Hank's solution containing $5.5 \mathrm{mM}$ glucose. Then $10 \mathrm{mM}$ methylsuccinate was added in the presence $(0)$ and absence $(\bullet)$ of $3 \mathrm{mM}$ sucralose. In some experiments, $3 \mathrm{mM}$ sucralose alone $(\mathrm{O})$ was added as indicated by the arrow. Values are the mean $\pm \mathrm{SE}$ of three determinations and the representative of three experiments. D: Quantitative Analysis of the Effects of Methylsuccinate and Sucralose on $[\mathrm{ATP}]_{\mathrm{i}}$. Changes in $[\mathrm{ATP}]_{\mathrm{i}}$ were measured as mentioned in $\mathrm{C}$ and AUC was calculated. Values are the mean \pm SE for three experiments.

\section{Discussion}

In the present study, we monitored changes in $[\mathrm{ATP}]_{\mathrm{i}}$ in living MIN6 cells. As shown in Fig. 1A, elevation of ambient glucose concentration from $5.5 \mathrm{mM}$ to 8.3 $\mathrm{mM}$ or higher resulted in biphasic elevation of $[\mathrm{ATP}]_{\mathrm{i}}$. The $[\mathrm{ATP}]_{\mathrm{i}}$ levels were reduced by adding an inhibitor of glucokinase and a mitochondrial uncoupler. In addition, administration of mitochondrial fuel elevated $[\mathrm{ATP}]_{\mathrm{i}}$. Moreover, these results are in accordance with that obtained by using Perceval, an indicator of ATP/ADP ratio [11]. Collectively, we could monitor dynamic changes in ATP in MIN6 cells in our experimental system.

Using this monitoring system, we demonstrated for the first time that relatively low concentrations of sucralose markedly elevated $[\mathrm{ATP}]_{\mathrm{i}}$. In fact, $[\mathrm{ATP}]_{\mathrm{i}}$ response to $5 \mathrm{mM}$ sucralose is almost comparable to that induced by $25 \mathrm{mM}$ glucose. Since sucralose is a non-fuel artificial sweetener not metabolized in $\beta$-cells 

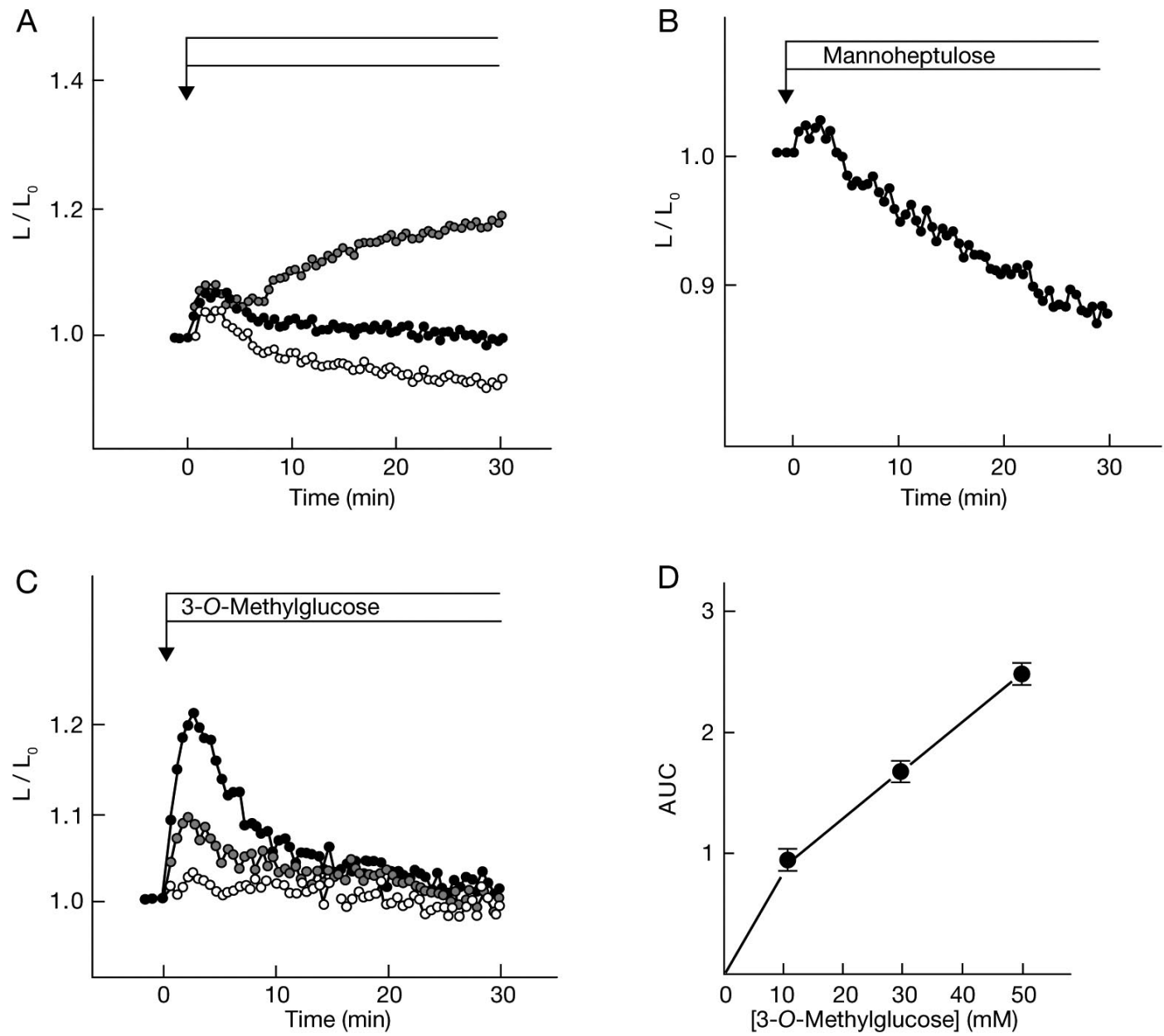

Fig. 4 Effects of non-metabolizable glucose analogues on $[\mathrm{ATP}]_{\mathrm{i}}$

A: Effect of Glucose, 3-O-Methylglucose and 2-Deoxyglucose on [ATP $]_{i}$. MIN6 cells were incubated in Hank's solution containing $5.5 \mathrm{mM}$ glucose. Then $25 \mathrm{mM}$ 3-O-methylglucose $(\bullet)$ or $25 \mathrm{mM}$ 2-deoxyglucose $(\mathrm{O})$ was added as indicated by the arrow. In some experiments, ambient glucose was changed from $5.5 \mathrm{mM}$ to $25 \mathrm{mM}$ glucose $(0)$. Values are the mean $\pm \mathrm{SE}$ of three determinations and the representative of three experiments. B: Effect of Mannoheptulose on [ATP] $]_{\mathrm{i}}$. MIN6 cells were incubated in Hank's solution containing $5.5 \mathrm{mM}$ glucose. Then $10 \mathrm{mM}$ mannoheptulose was added as indicated. Values are the mean $\pm \mathrm{SE}$ for three determinations and the representative of three experiments. C: Effect of 3-O-Methylglucose on $[\mathrm{ATP}]_{\mathrm{i}}$. MIN6 cells were incubated in Hank's solution containing $5.5 \mathrm{mM}$ glucose. Then, $11 \mathrm{mM}(\mathrm{O}), 25 \mathrm{mM}(\bullet)$ or $50 \mathrm{mM}(\bullet)$ 3-Omethylglucose was added as indicated by the arrow. Values are the mean $\pm \mathrm{SE}$ of three determinations and the representative of five experiments. D: Dose-response Relationship for the effect of 3-O-Methylglucose. Changes in $[\mathrm{ATP}]_{\mathrm{i}}$ were measured as mentioned in B and AUC was calculated. Values are the mean $\pm \mathrm{SE}$ for five experiments.

[14], elevation of $[\mathrm{ATP}]_{\mathrm{i}}$ may be due to promotion of metabolism of fuels including glucose. Although short term removal of ambient glucose did not abolish the sucralose-induced elevation of $[\mathrm{ATP}]_{\mathrm{i}}$, depletion of substrates may not have been achieved by the shortterm deprivation of ambient glucose. Alternately, other substrates were utilized for the generation of ATP. It is well known that the rate-limiting step in the glycolytic pathway is the phosphorylation of glucose catalyzed by glucokinase [15]. The site of sucralose action perhaps locates distal to this enzyme and at least partly locates in mitochondria since sucralose augmented $[\mathrm{ATP}]_{\mathrm{i}}$ response to mitochondrial fuel methylsuccinate. The exact site of action of sucralose is not identified at present. In any event, activation of the homodimer of T1R3 efficiently facilitates metabolism in mitochondria. This effect of sucralose was quite unique in the sense that potentiators of insulin secretion, for example, GLP-1 or carbachol did not reproduce the effect of sucralose. Furthermore, elevation of $\left[\mathrm{Ca}^{2+}\right]_{\mathrm{c}}$ induced 

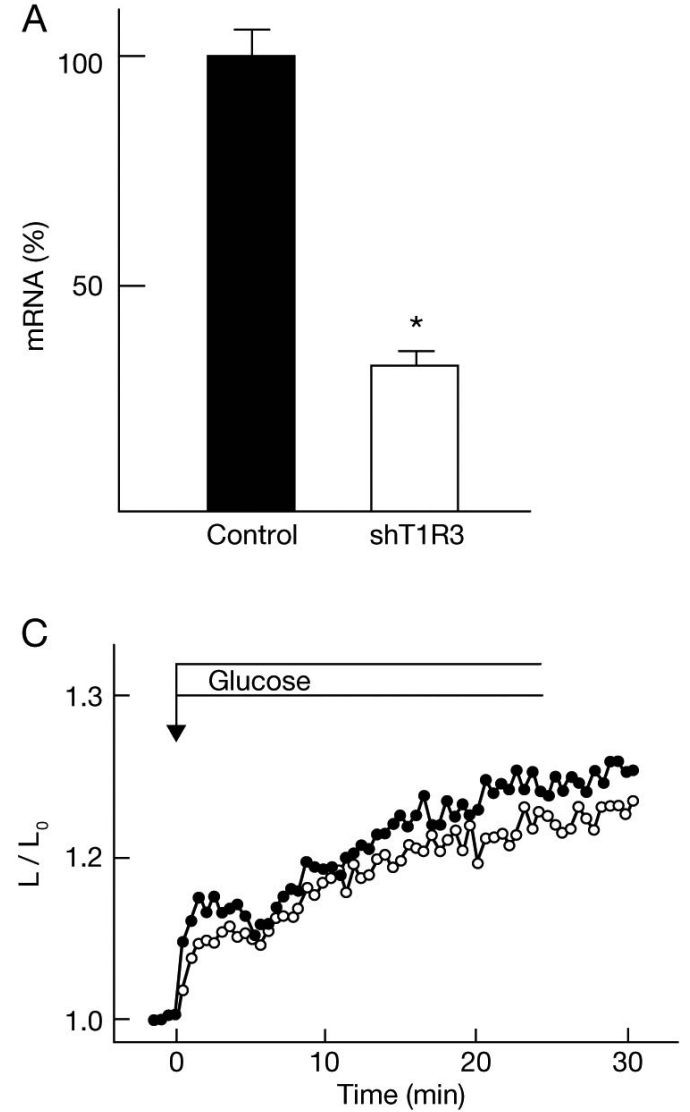
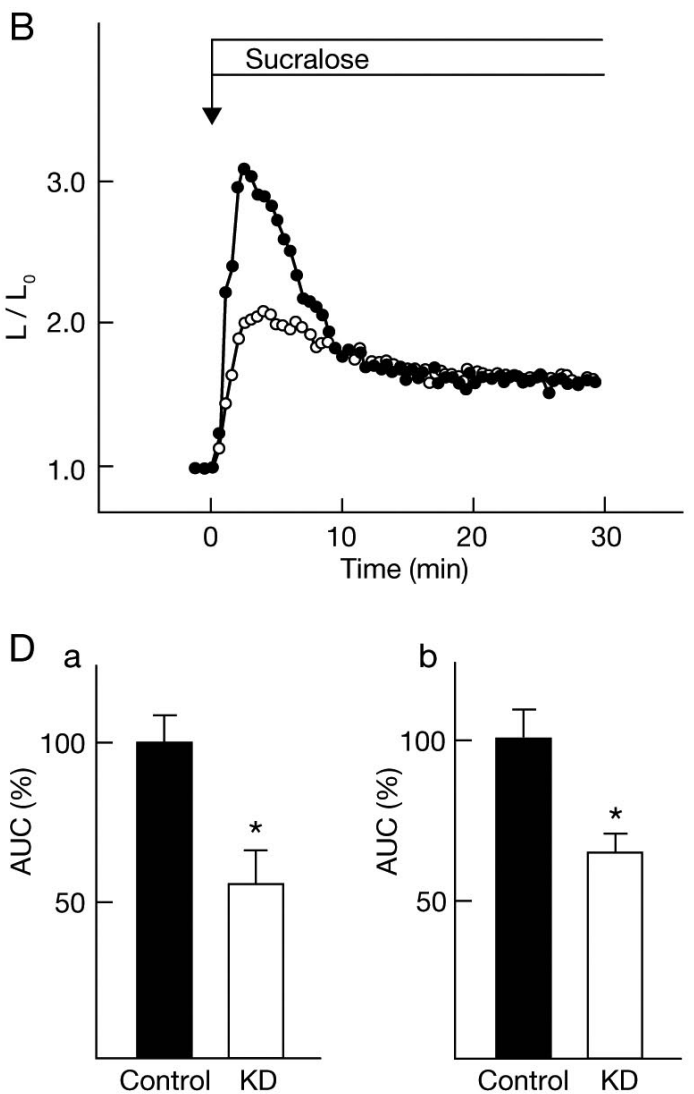

Fig. 5 Effect of knock down of T1R3

A: T1R3 was knocked down by using shRNA as described in Methods. The expression of T1R3 in control and knocked down cells (shT1R3) was measured by quantitative RT-PCR. ${ }^{*}, p<0.01$ vs control B: ATP response to 3 mM sucralose was measured in control $(\bullet)$ and T1R3-knocked down cells $(O)$. Values are the mean \pm SE for three determinations and the representative of three experiments. C: ATP response to $25 \mathrm{mM}$ glucose was measured in control (•) and T1R3-knocked down cells $(O)$. Values are the mean $\pm \mathrm{SE}$ for three determinations and the representative of three experiments. D: Quantification of the Effect of T1R3 Knock Down. Experiments were carried out as shown in C and the effect of T1R3 knock down on $[\mathrm{ATP}]_{\mathrm{c}}$ was quantified by calculating AUC from 0 to $5 \mathrm{~min}$ (a) and from 5 to $30 \mathrm{~min}$ (b). Values are the mean $\pm \mathrm{SE}$ for six experiments. ${ }^{*}, p<0.05$ vs control

by depolarizing concentration of potassium was ineffective to fully reproduce the effect of sucralose on $[\mathrm{ATP}]_{\mathrm{i}}$. We are currently studying signal transduction mechanisms involved in sucralose-mediated promotion of metabolism.

Other intriguing results obtained in this study are the effects of non-metabolizable analogue of glucose. As shown in Fig. 4A, non-metabolizable glucose analogues 3-O-methylglucose and 2-deoxyglucose transiently increased $[\mathrm{ATP}]_{\mathrm{i}}$, which corresponded to the first small peak of the glucose-induced biphasic elevation of $[\mathrm{ATP}]_{\mathrm{i}}$. There is, however, a difference in the action of 3-O-methylglucose and 2-deoxyglucose. In the case of 3-O-methylglucose, $[\mathrm{ATP}]_{\mathrm{i}}$ remained in the basal level after the initial peak whereas 2-deoxyglu- cose progressively reduced $[\mathrm{ATP}]_{\mathrm{i}}$ to the levels below the base line. This difference may be explained by the fact that 2-deoxyglucose but not 3-O-methylglucose is an inhibitor of glucokinase. In accordance with this notion, mannoheptulose, an inhibitor of glucokinase with sweet taste, essentially reproduced the action of 2-deoxyglucose (Fig. 4A and 4B). Collectively, the gradual decrease in $[\mathrm{ATP}]_{\mathrm{i}}$ in the sustained phase of 2-deoxyglucose action may be due to the inhibition of glucokinase. In contrast to 2-deoxyglucose, 3-Omethylglucose does not affect glucokinase activity [16] although very high concentration of 3-O-methylglucose inhibits glucose transport by a competitive mechanism [17]. Hence, the transient elevation of $[\mathrm{ATP}]_{\mathrm{i}}$ induced by $3-O$-methylglucose may be due to activa- 

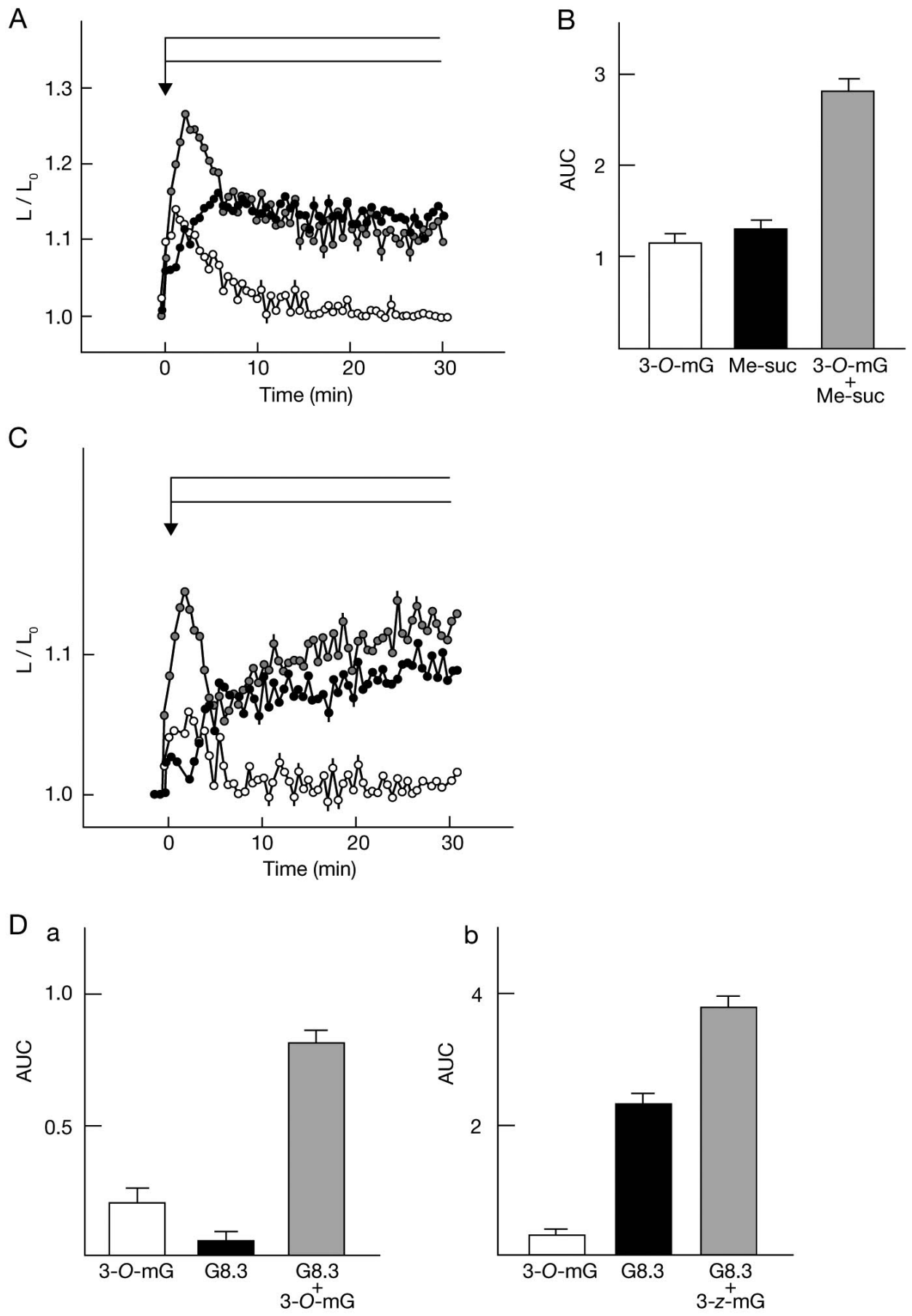

Fig. 6 Effect of 3-O-methylglucose on elevation of $[\mathrm{ATP}]_{\mathrm{i}}$ induced by methylsuccinate

A: Effect of 3-O-methylglucose and/or Methylsuccinate on $[\mathrm{ATP}]_{\mathrm{i}}$. MIN6 cells were incubated in Hank's solution containing $5.5 \mathrm{mM}$ glucose. Then, $25 \mathrm{mM} 3-O$-methylglucose $(\bigcirc), 3 \mathrm{mM}$ methylsuccinate $(\bullet)$ or 3-O-methylglucose + methylsuccinate ( $\mathrm{C}$ ) was added as indicated by the arrow. Values are the mean \pm SE of three determinations and the representative of three experiments. B: Quantitative Analysis of the Effects of 3-O-Methylglucose and Methylsuccinate. Experiments were done as described in A and AUC was calculated. Values are the mean $\pm \mathrm{SE}$ for three experiments. C: Effect of 3-O-Methylglucose and/or Glucose on $[\mathrm{ATP}]_{\mathrm{i}}$. MIN6 cells were incubated in Hank's solution containing $5.5 \mathrm{mM}$ glucose. Then, $25 \mathrm{mM} 3-\mathrm{O}$ methylglucose $(O), 8.3 \mathrm{mM}$ glucose $(\bullet)$ or both $(\bigcirc)$ was added as indicated by the arrow. Values are the mean $\pm \mathrm{SE}$ of three determinations and the representative of three experiments. D: Quantitative Analysis of the Effects of 3-O-Methylglucose and Glucose. Experiments were done as described in C and AUC was calculated. AUCs from time 0 to 5 min (a) and form 5 min to $30 \mathrm{~min}(\mathrm{~b})$ were calculated. Values are the mean $\pm \mathrm{SE}$ for three experiments. 


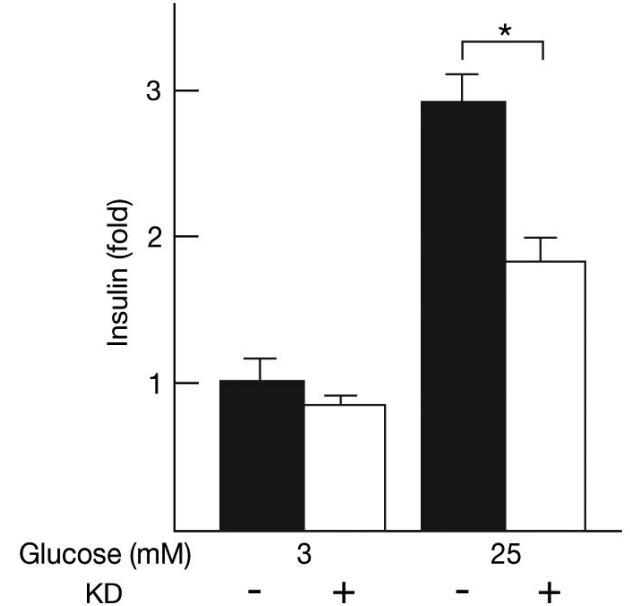

Fig. 7 Effect of T1R3 knock down on glucose-induced insulin secretion

Control ( $\square$ ) and T1R3-knocked down ( $\square$ ) MIN6 cells were incubated for $60 \mathrm{~min}$ in the presence of 3 or $25 \mathrm{mM}$ glucose and secreted insulin was measured. Values are the mean $\pm \mathrm{SE}$ for four experiments. ${ }^{*}: P<0.05 v s$ control.

tion of the homodimer of T1R3. In accordance with this notion, the transient elevation of $[\mathrm{ATP}]_{\mathrm{i}}$ was attenuated in cells with reduced T1R3 expression (data not shown). Indeed, 3-O-methylglucose-induced elevation of $[\mathrm{ATP}]_{\mathrm{i}}$ is the first demonstration of the glucose effect mediated by the homodimer of T1R3. Hence, a homodimer of T1R3 acts as a cell-surface glucosesensing receptor. The effect of 3-O-methylglucose was detected at $11 \mathrm{mM}$. Since 3-O-methylglucose is not metabolized by glucokinase, increase in $[\mathrm{ATP}]_{\mathrm{i}}$ is not due to an increase in the amount of substrate. Rather, it may be due to the activation of the metabolic pathway via the glucose-sensing receptor T1R3. Presumably, glucose in cytosol under basal condition may be metabolized more efficiently and ATP was generated. These observations clearly show that a high concentration of glucose acts on the cell surface glucose-sensing receptor in one hand and then enters the cells via glucose transporters. The glucose effect mediated by the glucose-sensing receptor is rapid, indicating that the initial $[\mathrm{ATP}]_{\mathrm{i}}$ response to glucose is mediated by this receptor. The effect appears small and transient. Nevertheless, the signal exerted by the glucose-sensing receptor is also effective in facilitation of the mitochondrial metabolism since 3-O-methylglucose potentiated the $[\mathrm{ATP}]_{\mathrm{i}}$ response to methylsuccinate (Fig. $6 \mathrm{~A}$ and $6 \mathrm{~B})$. Furthermore, the second phase of the $[\mathrm{ATP}]_{\mathrm{i}}$ response to $8.3 \mathrm{mM}$ glucose was augmented by $3-O-$ methylglucose (Fig. 6C and 6D). Collectively, the glucose signal mediated by the glucose-sensing receptor has two roles. First, it rapidly facilitates the metabolism in mitochondria and generates ATP by using preexisting substrates. Second, it promotes metabolism and generates ATP using substrates supplied by glycolysis of glucose entered into $\beta$-cells.

Insulin secretion was studied in $\beta$-cells obtained from mice lacking the T1R3 gene [18]. Although the gross insulin secretory response to glucose is not changed, analysis of exocytotic fusion of the insulin granules revealed that rapid exocytosis is markedly attenuated in T1R3-null $\beta$-cells. These results are consistent with our observation that glucose signal mediated by the glucose-sensing receptor is critical for rapid production of ATP. Presumably, gross metabolism of glucose was compensated by chronic deletion of T1R3 in T1R3-null mice. However, the rapid response of ATP mediated by the glucose-sensing receptor could not be compensated. Further study is clearly necessary to examine this notion.

The present results reveal a novel aspect of the action of glucose in pancreatic $\beta$-cells. Glucose does not only enter $\beta$-cells passively and serve as a substrate for oxidative reactions leading to ATP production, it also acts on the cell surface glucose-sensing receptor and generates signals to activate the metabolic pathway. With regard to the time sequence, glucose first binds to the glucose-sensing receptor, activates the receptor, generates intracellular signal(s) and sensitizes its metabolic pathway. Then, glucose enters the cells via the glucose transporter, and is catalyzed through the primed metabolic pathway leading to generation of ATP (Fig. 8). Hence, the present results support the "glucoreceptor model" or the "regulator-site model" proposed by Niki et al. [19] and extend the models in so far as the glucose-sensing receptor signal activates the metabolic pathway and promotes the metabolism of glucose. Interaction of the glucose-sensing receptor signals and metabolic signals may be a basis for the efficient glucose sensing mechanism of $\beta$-cells as a fuel sensor. In $\beta$-cells, the sweet taste-sensing receptor senses fructose as well [20]. Pancreatic $\beta$-cells thus express cell-surface sugar-sensors to regulate insulin secretion.

We have to mention that the present study was performed in a clonal $\beta$-cell line, MIN6. Perhaps glucosesensing machinery may be slightly different from that in islet $\beta$-cells. For example, MIN6 cells are less sen- 

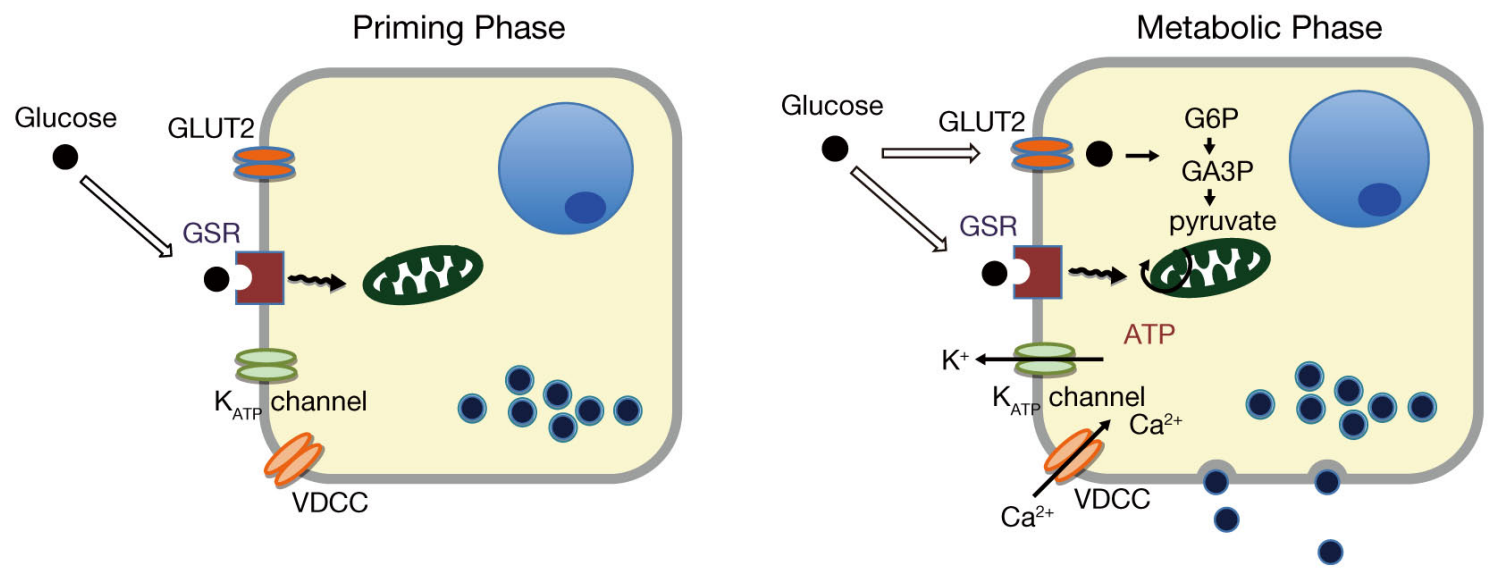

Fig. 8 A schematic presentation of the action of glucose

Glucose first acts on the cell surface glucose-sensing receptor (GSR), which generates a signal to facilitate metabolism in mitochondria (Priming Phase). Glucose then enters the cell via glucose transporter and is then metabolized through the glycolytic pathway. Increase in the amount of substrates together with the signal via the GSR lead to production of ATP (Metabolic Phase).

sitive to glucose as compared to $\beta$-cell [10]. Probably because of this, $[\mathrm{ATP}]_{\mathrm{i}}$ response to glucose is biphasic in MIN6 cells [21] whereas islet $\beta$-cells present monophasic increase in $[\mathrm{ATP}]_{\mathrm{i}}[22]$. It is an interesting question whether the glucose-sensing receptor signals also modulate the metabolic pathway in islet $\beta$-cells. Further study is clearly needed to reevaluate the nature of the glucose-sensing machinery in pancreatic $\beta$-cells.

\section{Acknowledgements}

The authors are grateful to Mayumi Odagiri for secretarial assistance.

\section{Disclosure}

None of the authors have any potential conflicts of interest associated with this research.

\section{References}

1. Rorsman P (1997) The pancreatic $\beta$-cell as a fuel sensor. Diabetologia 40: 487-495.

2. Henquin JC (2009) Regulation of insulin secretion: a matter of phase control and amplitude modulation. Diabetologia 52: 739-751.

3. Komatsu M, Sato Y, Aizawa T, Hashizume K (2001) $\mathrm{K}_{\text {ATP }}$ channel-independent glucose action: an elusive pathway in stimulus-secretion coupling of pancreatic B-cells. Endocr J 48: 275-288.

4. Nakagawa Y, Nagasawa M, Yamada S, Hara A, Mogami $\mathrm{H}$, et al. (2009) Sweet taste receptor expressed in pancreatic $\beta$-cells activates the calcium and cyclic AMP signaling systems and stimulates insulin secretion. PLoS One 4: e5106.

5. Temussi P (2007) The sweet taste receptor: a single receptor with multiple sites and model of interaction. Adv Food Nutr Res 53: 199-239.

6. Roper SD (2007) Signal transduction and information processing in mammalian test buds. Pflugers Arch 454:
759-776.

7. Kojima I, Nakagawa Y (2011) The role of the sweet taste receptor in enteroendocrine cells and pancreatic $\beta$-cells. Diabetes Metab J 34: 451-457.

8. Henquin JC (2012) Do pancreatic $\beta$-cells "taste" nutrients to secrete insulin? Sci Signal 5: pe36.

9. Nakagawa $\mathrm{Y}$, Nagasawa M, Mogami H, Lohse M, Ninomiya Y, et al. (2013) Multimodal function of the sweet taste receptor expressed in pancreatic $\beta$-cells: generation of multiple patterns of intracellular signals by sweet agonists. Endocr J 60: 1191-1206.

10. Miyazaki J, Yamato E, Ikegami H, Asano T, Shibasaki Y, et al. (1990) Establishment of a pancreatic beta cell line that retains glucose-inducible insulin secretion: special reference to expression of glucose transporter isoforms. Endocrinology 127: 126-132.

11. Berg J, Hung YP, Yellen G (2009) A genetically encoded fluorescent receptor of ATP: ADP ratio. Nat Methods 6: 161-166. 
12. Miwa I, Murata T, Mitsuyama S, Okuda J (1990) Participation of glucokinase inactivation in inhibition of glucose-induced insulin secretion by 2-cyclohexen1-one. Diabetes 39: 1170-1176.

13. Malaisse WJ, Sener A, Lery J (1976) The stimulus secretion coupling of glucose-induced insulin release. Fasting-induced adaptation in key glycolytic enzymes in isolated islets. $J$ Biol Chem 251: 1731-1737.

14. Quinlan ME, Jenner MFt (1990) Analysis and stability of the sweetener sucralose in beverages. J Food Sci 55: 244-246.

15. Ashcroft SJH, Randle PJ (1969) Metabolism and insulin secretion in isolated islets. Acta Diabetol Lat 6 (suppl 1): 538-553.

16. Zawalich WS, Pagliara AS, Matchinsky FM (1977) Effects of iodoacetate, mannoheptulose and 3-O-methylglucose on secretory function and metabolism of isolated pancreatic islets. Endocrinology 100: 1276-1283.

17. Sener A, Scruel O, Lonchami K, Jijakli H, Malaiise WJ (1999) Inhibition of glucose-induced insulin release by 3-O-methyl-D-glucose: enzymatic, metabolic and cat- ionic determinants. Mol Cell Biochem 194: 133-145.

18. Geraedts MC, Takahashi T, Vigues S, Markwardt ML, Nkobena A, et al. (2012) Transformation of postingestive glucose responses after deletion of sweet receptor subunits or gastric bypass surgery. Am J Physiol 303: E464-E474.

19. Niki A, Niki H, Miwa I, Okuda J (1974) Insulin secretion by anomers of D-glucose. Science 186: 150-151.

20. Kyriazis GA, Soundarapandian MM, Tyrberg B (2012) Sweet taste receptor signaling in beta cells mediates fructose-induced potentiation of glucose-stimulated insulin-secretion. Proc Natl Acad Sci USA 109: E524E532.

21. Li J, Shuai HY, Gylfe E, Tengholm A (2013) Oscillations of sub-membrane ATP in glucose-stimulated beta cells depend on negative feedback from $\mathrm{Ca}^{2+}$. Diabetologia 56: $1577-1586$.

22. Ishihara $\mathrm{H}$, Maechler $\mathrm{P}$, Gjinovci A, Herrera PL, Wollheim CB (2003) Islet beta-cell secretion determines glucagon release from neighbouring alpha-cell. Nat Cell Biol 5: 330-335. 